\title{
NOTE.
}

\section{NOTE ON THE BIOLOGY OF THE GENUS SEPTOBASIDIUM.--}

The genus Septobasidium, Pat., was instituted for the reception of a fairly well-defined group of Basidiomycetous Fungi which had been included by previous authors under Thelephora, Lachnocladium, Corticium, \&c. They are practically confined to tropical countries, and therefore very little has been recorded concerning their biology. As a rule they are found, encrusting living stems or leaves, up to a height of ro feet or more from the ground. In Ceylon, several species, or forms, are quite common, though it is difficult to determine how many species occur, because the majority of the specimens collected are sterile, and in that condition they are all very much alike. One species (? Corticium murinum, B. and Br.) frequently causes alarm by clothing the stems of tea bushes from top to bottom; another (Thelephora lichenicola, B. and Br.) forms brown sheets which extend for a length of several feet along the stems of mango trees; while two others (Thelephora suffulta, B. and Br., and Lachnocladium rameale, $\mathrm{B}$. and $\mathrm{Br}$.) similarly encrust the twigs of shrubs in up-country jungles. But as the stems, twigs, or leaves are in no case killed or noticeably injured by the fungi, one is immediately led to question their supposed parasitism.

From an examination of a long series of specimens, it has been determined that these Fungi are parasitic on colonies of scale insects, which they overgrow and destroy completely. One purple-black species which is fairly common on tea always grows over the insect Chionaspis biclavis, as was pointed out to me by Mr. E. E. Green: An examination of the specimens in the Kew herbarium demonstrates that this habit is not confined to Ceylon species, for a sterile specimen there from North America, included under Thelephora lichenicola, also shows a colony of scale insects beneath the subiculum.

These Fungi live, not on the secretions of the insects, as in the case of Meliola, but upon the insects themselves: biologically, therefore, they afford a parallel to the genus Hypocrella among the Pyrenomycetae.

T. PETCH.

[Annals of Botany, Vol. XXV. No. XCIX. July, rgir.] 


\section{$2 \mathrm{BHL}$ Biodiversity Heritage Library}

Petch, T. 1911. "Note on the biology of the genus Septobasidium." Annals of botany 25, 843-843. https://doi.org/10.1093/oxfordjournals.aob.a089356.

View This Item Online: https://www.biodiversitylibrary.org/item/239487

DOI: https://doi.org/10.1093/oxfordjournals.aob.a089356

Permalink: https://www.biodiversitylibrary.org/partpdf/319864

\section{Holding Institution}

Smithsonian Libraries

\section{Sponsored by}

Biodiversity Heritage Library

\section{Copyright \& Reuse}

Copyright Status: Not in copyright. The BHL knows of no copyright restrictions on this item.

This document was created from content at the Biodiversity Heritage Library, the world's largest open access digital library for biodiversity literature and archives. Visit BHL at https://www.biodiversitylibrary.org. 